\title{
PTSD and Agent Orange: Implications for a Sociology of Veterans' Issues
}

WILBUR J. SCOTT

\section{A} bout 2.9 million American troops served in the Vietnam War between 1964 and 1975. Of these, more than 58,000 died and another 300,000 were wounded. This represents a higher wounded-to-killed ratio than in the two world wars and Korea. The number of psychiatric casualties in Vietnam on average was 12 per 1,000 troops per year, about the same as for Army personnel stationed in the continental United States during the same time and a figure much lower than for American troops during the Second World War and Korea. However, since 1975 about 700,000 Vietnam veterans have sought counseling or other help from the Veterans Administration for readjustment difficulties. Further, about 250,000 Vietnam veterans have requested physical examinations from the VA to access suspicions that exposure to the herbicide, Agent Orange, caused their health problems.

This article focuses on selected experiences of Vietnam veterans after their return to the United States. By exploring the politics of their readjustment to civilian life, I develop a preliminary "sociology of veterans' issues." It is assumed that collective sentiments about a specific war influence the readjustment of each generation of veterans, and that health care issues are a central feature of the readjustment process. There are two reasons for the salience of health care issues. First, they invoke culturally defined notions about what constitutes the normal experience of soldiers during and after a war and, second, they raise important questions about liability and compensation for injuries and disabilities incurred while in the military.

WILBUR J. SCOTT is associate professor of sociology at the University of Oklahoma. His areas of interest are the sociology of politics, social change, and military sociology. His recent research focuses on Vietnam veterans and the politics of their readjustment. His articles have appeared in Social Problems, and in the series Perspectives on Social Problems. Address for correspondence: Professor Wilbur J. Scott, Department of Sociology, University of Oklahoma, Norman, OK, 73019. 
Controversies over the legitimacy of Posttraumatic Stress Disorder (PTSD) as a psychiatric diagnosis and over the consequences of exposure to Agent Orange reveal the politics of readjustment for Vietnam veterans. Over the past six years, I have reviewed published materials about these issues and have conducted interviews with many of the key protagonists in the Vietnam veteran, health care, and research communities. ${ }^{1}$ What follows is a synthesis of my impressions and a preliminary theory of veterans' issues.

\section{A Constructivist Approach to Veterans' Issues}

Medical sociologists have found it useful to distinguish the terms disease, illness, and sickness. Disease refers to a condition that impairs bodily functions. The perception by the individual that he or she does not feel well, that something is wrong, is known as illness. Sickness occurs when appropriate medical authorities confirm that an individual has a disease and therefore may legitimately report feeling ill.

These distinctions invite the recognition that sickness and its consequences may differ from the person's biological state. While sickness may have some biological basis, not all diseased people are permitted to act sick and some people who are permitted to act sick are not diseased. In disputes about whether someone is sick - and about the extent and source of the sickness - the assumptions, values, and interests of several institutions come into play. In contemporary society, these include science, health care delivery systems, and the courts. The VA is the health care delivery system and institution that certifies the illnesses of veterans as sicknesses.

Two schools of thought exist with respect to this characterization of disease, illness, and sickness. ${ }^{2}$ The objectivist school, by far the more dominant of the two, presumes that self-evident diseases exist in the "real" world. When these diseases afflict enough persons, the evidence accumulates and invites discovery of such diseases as sicknesses. While not dismissing political considerations entirely, objectivists believe that the task is methodological: if medical and governmental authorities develop and employ appropriate scientific principles, the facts will emerge and, to a significant extent, speak for themselves.

In contrast, the constructivist school denies any necessary connection between injury or disease and the likelihood of recognition. Here the certification of sicknesses is an inherently political process: interested persons and interest groups advocate ideas about what is problematic, 
focus on certain kinds of evidence, and use available resources to establish claims. Constructivists contend that interested parties move disputed claims along a path toward acceptance as a taken-for-granted fact. This calls for appropriate documentation, the ability to command the attention and respect of critical persons and groups, and the skills and resources to marshal this effort. The constructivist view guides the observations presented in this article.

Veterans of all U.S. wars have encountered similar pitfalls in requesting medical treatment and compensation for service-connected injuries and disease. I propose three reasons for this. First, the military in time of war often uses new weaponry or other inventions that have unforeseen consequences. This occurs because technological innovation proceeds more rapidly than the cultural or structural adjustments to them ${ }^{3}$ and because the effects of combat on its participants are imperfectly understood. The repercussions often include unanticipated diseases and injuries that the medical world is ill-equipped to handle. Many veterans therefore exhibit illnesses and injuries that challenge the limits of existing medical knowledge. This may result in an increase in medical innovation and change, the systematic misdiagnosis and improper treatment of veterans' illnesses, or both.

Second, veterans often encounter difficulties more than a year after discharge that nonetheless are caused by experiences or conditions in the military. ${ }^{4}$ Latent disorders are diseases in which there is a substantial time lag between precipitating event and the emergence of debilitating symptoms. These diseases fall outside the criterion of temporal coincidence for service connection and make the determination of cause and effect very difficult. The time lag between exposure and consequence strains the ability to establish evidence. Even in dramatic instances of disease, observers may pose rival explanations with no way to judge between them.

Third, in the years following a war, conflict often arises while veterans adjust to civilian life and the populace shoulders its debt to veterans. The "free-rider" principle helps explain why this takes place. The principle predicts the likely reactions when the costs of a policy are specific while the benefits are diffuse (or vice versa). ${ }^{5}$ Specifically, during wartime, a nation typically meets military manpower needs through altruistic service by patriotic soldiers. When the war ends, the patriotic service remains "priceless" - that is, it cannot be reimbursed at "market-value," while medical care and compensation for veterans carry specific price tags and compete for priority in limited budgets. The veterans are, in a sense, infinitely deserving, while resources are finite. Hence, the certifica- 
tion of sicknesses among veterans - in the constructivist view, an inherently political process in any circumstance - often is bitterly contested as altruistic service clashes with fiscal constraints and political realities.

For these reasons, the study of veterans' issues often affords the opportunity to illuminate the politics of disease and its certification as sickness. Individual veterans, organizations, and government entities may become embroiled in disputes over blame and responsibility. Interest groups may form as advocates of different perspectives and evidence. When this occurs, observers and participants may draw contradictory conclusions by asking the same questions in different domains, and conflicts may emerge over whose version to accept as true. The controversies may become convenient and symbolic media for venting other antagonisms. In the protracted period of suffering and haggling, frustration and delusion may become a prominent feature of the veterans' response.

The PTSD and Agent Orange controversies encompass many of these considerations and thereby provide ideal instances for examining the sociopolitical process of readjustment in the Vietnam era.

\section{The Politics of PTSD}

The most influential body in Congress affecting legislation pertaining to veterans has been the House Committee on Veterans' Affairs. Along with the VA and the major veterans organizations - the American Legion, Veterans of Foreign Wars (VFW), and Disabled American Veterans - the committee is part of what is often called the "Iron Triangle."

Rep. Olin "Tiger" Teague (D-Tex.) chaired the House Committee on Veterans' Affairs from 1955 to 1973 and remained its most influential member until 1979. The most highly decorated Second World War veteran in Congress, Teague had firm ideas about what legislation veterans needed and how to develop that legislation. The American Legion, VFW, and Disabled American Veterans - the second side of the triangle - provided veterans of both world wars and of Korea with political input and fraternal support. However, these organizations attracted very few veterans of the Vietnam War to their ranks. ${ }^{6}$

During the 1950s and 1960s, the VA catered mainly to the 12 million veterans of the Second World War, who on the average were then in their mid-40s and mid-50s and increasingly had chronic ailments associated with aging rather than warfare. As veterans of the Second World War aged, the major veterans organizations lobbied Congress for programs and expenditures to meet their changing needs. While it did not serve as a 
rubber stamp, the House committee did sponsor corresponding legislation, and the VA put it into practice. Consequently, 70 percent of the patients treated by the VA in 1965 had disabilities that were not serviceconnected and, of all medical treatment provided by the VA, almost 85 percent was for problems that were not service-connected. As the Vietnam War progressed, the VA suddenly experienced an influx of younger veterans requiring treatment, rehabilitation, and compensation for war-related injuries and diseases. This produced tremendous strains in a health care system by now accustomed to addressing the needs of older veterans with ailments unrelated to war. One of the points of contention was war neurosis or, as it was called later, PTSD.

The politics of PTSD has its roots in the history of war neurosis as an official diagnosis. ${ }^{7}$ During the First World War, British military psychiatrists used the term "shell shock" to denote the dazed, disoriented state many soldiers experienced during combat, attributing the condition to physiological damage caused by exploding artillery shells. However, many military leaders and physicians contended that shell shock was a variety of cowardice or malingering and that those who "cracked" on the battlefield were weaklings. After the war, Sigmund Freud argued that shell shock was psychological in origin. He distinguished it from the more common neuroses that originate during childhood and recommended psychoanalysis as the treatment for both. As other well-known psychiatrists agreed with Freud's position, physiological explanations for shell shock fell into disfavor.

During the Second World War, the military sought to screen out marginally adjusted inductees. Draft boards in the United States declared more than one million men psychologically unfit to fight. Nevertheless, the U.S. military experienced high rates of psychiatric casualties. Military psychiatrists noted that those suffering had passed screening standards, and some were seasoned troops who previously had fought bravely. Medical personnel, and the troops themselves, commonly called the condition "combat fatigue."

In 1952, the American Psychiatric Association (APA) published the first edition of its Diagnostic and Statistical Manual (DSM-I). Drawing on the work of military psychiatrists in the Second World War and Korea, ${ }^{8}$ DSM-I contained the entry "gross stress reaction." The editors described the reaction as a temporary condition produced by extreme environmental stress and said it could occur among combat soldiers who showed no previous history of mental problems. The reaction, they concluded, should disappear after the individual exited the combat zone.

DSM-II, published in 1968, included several diagnoses not listed pre- 
viously and omitted several that had appeared in DSM-I. Among those omitted was gross stress reaction. Some psychiatrists disagreed with this decision. For example, Herbert Archibald and Read Tuddenham, who had conducted 15- and 20-year follow-up studies of World War II and Korean War veterans, affirmed the significance of the gross stress reaction diagnosis and documented the persistence of symptoms long after these wars were over. ${ }^{9}$ However, these psychiatrists did not realize that the status of gross stress reaction was in doubt until after the manual's publication.

Many clinicians and researchers, in and out of the VA, soon noticed a new wrinkle in the case of Vietnam veterans. Military and VA records revealed that the incidence of war neurosis in the Second World War and Korea increased as combat intensified, and declined to low levels in the postwar era. In the Vietnam War the number of psychiatric casualties was very low in the combat zone, but many veterans appeared to have difficulties after returning home. ${ }^{10}$ Since DSM-II provided the list of official diagnoses, mental health professionals across the country assessed disturbed Vietnam veterans using a nomenclature that contained no specific entries for war-related trauma. Thus, VA psychiatrists typically did not collect military histories as part of the diagnostic workup, and many assumed that Vietnam veteran patients suffered from neuroses or psychoses whose origins lay outside the realm of combat. VA psychiatrist Arthur Blank, who became the the VA's chief of psychological services in 1980, described the situation in these years as "dysfunctional and bizarre."11

Despite the absence of a listing in DSM-II, many psychiatrists still considered the listing in DSM-I, gross stress reaction, as diagnostically valid and useful. In 1969, psychiatrist John Talbott, in a critique of DSMII published in the International Journal of Psychiatry, recommended that future editors of DSM-III reintroduce the gross stress reaction listing. ${ }^{12}$ Similarly, adherence to the nomenclature within the VA varied according to therapists' personal and clinical experiences. Some VA psychiatrists informally collected military histories from patients they privately considered to be cases of war neurosis and altered the treatment plans accordingly. ${ }^{13}$

In November 1970, Vietnam Veterans against the War (VVAW), a small organization opposed to continued U.S. military involvement in Vietnam, requested advice from psychiatrists Robert Lifton and Chaim Shatan, themselves ardent opponents of the war effort. Both Lifton and Shatan had been concerned for some time about the absence of a combatstress diagnosis in DSM-II. Following their participation in VVAW's New York City "rap groups"-informal sessions in which veterans discussed their war experiences - Shatan wrote a series of articles in popular 
magazines and professional journals describing a "post-Vietnam syndrome." $14 \mathrm{He}$ argued that the disorder occurred from 9 to 30 months after return from combat in Vietnam. He described the syndrome as "delayed massive trauma" and identified its themes as guilt, rage, the feeling of being scapegoated, psychic numbing, and alienation. He emphasized that these were not an accidental grab bag of symptoms, but stemmed from the inability of soldiers to grieve in the combat zone.

In 1971, Sen. Alan Cranston (D-Calif.) of the newly formed Senate Committee on Veterans' Affairs introduced legislation to provide for the treatment of alcoholism and drug abuse specifically among Vietnam veterans. Cranston, a critic of the war, had become convinced that Vietnam veterans had special needs that the VA was not meeting. The cost of Cranston's bill for the recommended five-year period reflected less than one percent of the VA budget for those years. While the measure passed in the Senate, it died in the House Committee on Veterans' Affairs. Committee members, staunch supporters of the war led by Teague, disagreed that Vietnam veterans needed special programs. ${ }^{15}$ The American Legion and VFW lobbied aggressively against the measure. ${ }^{16}$ The Cranston bill passed the Senate again in 1973 and 1975, but encountered the same fate in the House committee that it had in $1971 .^{17}$

News that DSM-III was being developed appeared in the June 1974 edition of Psychiatric News. Shatan and Lifton felt that they had sufficient empirical evidence for a diagnostic category devoted to war neurosis. However, they knew that DSM-III would contain no listing for combatrelated disorders without concerted and effective effort on their part. Hence, with Vietnam veteran activist Jack Smith, they organized a small group of mental health professionals, informally called the Vietnam Veterans Working Group, to reintroduce such a diagnosis in DSM-III. ${ }^{18}$ In 1976, they proposed a diagnosis, catastrophic stress disorder, which would apply not only to Vietnam veterans but to anyone traumatized by an event that "falls outside the range of usual human experience." The disorder represented, they argued, a normal but dysfunctional response to human disfigurement and death, and occurred when events impeded the expression of grief associated with the traumatic event.

The proposal encountered scattered opposition. ${ }^{19}$ Opponents argued that the standard diagnostic categories of depression, schizophrenia, and alcoholism adequately covered the symptoms manifested by Vietnam veterans and the veterans of previous wars. Since the anti-war activity of Working Group members was well-known, some psychiatrists suspected that their politics colored the evidence. To combat this suspicion, the Working Group collected more than 700 case histories of Vietnam veter- 
ans and of civilians injured on the job, disaster victims, and concentration camp survivors. They presented their findings to the APA in 1978. The editors of DSM-III accepted the recommendation but changed the label of the diagnosis to "post-traumatic stress disorder" (PTSD). ${ }^{20}$

In January 1977, President Jimmy Carter appointed Max Cleland as the VA's national director. Cleland, a Vietnam veteran and triple amputee, previously had attended annual meetings of the APA representing the Senate Committee on Veterans' Affairs and was well versed in these developments. By now, Cranston's bill emphasized readjustment counseling to address PTSD. As the VA's new head, Cleland made it plain that he considered Cranston's bill a top priority. In 1977, however, the bill was defeated again in the House. When Cranston reintroduced his bill in 1978, a deal was in the works. In exchange for House support, the Senate committee offered to back House committee legislation allowing the Committees on Veterans' Affairs to have a say in choosing the location of future VA facilities. The issues of readjustment counseling and VA site selection were tied to a larger package of VA health care programs. As the deal unraveled in the final days of the session, the entire package of veterans' legislation died in the House committee.

In 1979, proponents of the Cranston bill moved quickly to reintroduce it. The debate over readjustment counseling in 1978 had felled the entire legislative package, affecting older veterans as well as veterans of the Vietnam War. This increased the political pressure in the House and Senate Committees on Veterans' Affairs to pass significant veterans legislation during the 1979 session. The same deal was on the table. The House committee decided to accept the offer. On its fifth try during the decade of the 1970s, readjustment counseling for Vietnam veterans passed both the Senate and the House without incident. ${ }^{21}$

Meanwhile, Cleland and his staff had designed a VA Outreach Program to implement the directives contained in the Cranston bill. The plan called for a radically new program addressing the needs of Vietnam veterans with PTSD who did not require standard psychiatric care. The plan located treatment facilities, called Vet Centers, away from other VA facilities and, in an unorthodox and controversial move, established a separate administrative structure to oversee them. ${ }^{22}$ It staffed the centers with paraprofessionals rather than psychiatrists or psychologists, often Vietnam veterans who received training from the VA specifically for the job. Therapy included individual counseling and rap groups that encouraged veterans to talk about their war experiences, family relationships, and the readjustment process. ${ }^{23}$ Cleland personally dedicated and opened the first Vet Center in a shopping mall in Van Nuys, Calif. in November 1979. By 1981, the VA had established 137 Vet Centers across the country. 


\section{The Politics of Agent Orange}

Ideally suited for guerrilla warfare, the dense jungles and forests of South Vietnam allowed Communist troops to fight when they had the advantage and hide when they did not. Therefore, as early as 1962 , the American military began defoliating combat areas by aerial spraying with several specially prepared herbicides. The most commonly used herbicide was Agent Orange, so named because of the color-coded 55 gallon drums in which it was stored. U.S. armed forces sprayed approximately 11 million gallons of Agent Orange between 1965 and 1971. An Air Force squadron, under the code name Operation Ranch Hand, sprayed most of the herbicide. ${ }^{24}$ In 1969 , a scientific study reported that laboratory animals exposed to trace amounts of dioxin, a latent by-product in Agent Orange, developed cancer and had offspring with birth defects. ${ }^{25}$ The military reacted by restricting the spraying program and subsequently stopped it in 1970.

The VA received the first claims contending illness and disability attributed to herbicides shortly after Cleland became the national director. A scattering of Vietnam veterans had collected circumstantial evidence linking their health problems to exposure to Agent Orange in Vietnam. The VA and the Department of Defense claimed there was no evidence of the herbicide's harmfulness to human beings. A sympathetic VA caseworker compiled files on about two dozen veterans who reported exposure to the herbicide. She turned the files over to Bill Kurtis, a reporter for WBBM-TV, Chicago's CBS affiliate. ${ }^{26}$ Sensing a big story, Kurtis put together a documentary, "Agent Orange: Vietnam's Deadly Fog," which WBBM aired on 23 March 1978. The story attracted national attention. ${ }^{27}$

A few months later, Paul Reutershan, a Vietnam veteran dying of stomach cancer, filed a claim with the VA contending that his exposure to Agent Orange while flying helicopters in Vietnam caused the cancer. The VA acknowledged that he had cancer but denied that Agent Orange caused it. The doctrine of sovereign immunity and its related principle of intramilitary immunity, the Feres Doctrine, prohibit veterans from suing the government for damages incurred during military service. Further, congressional legislation prohibits veterans from suing the VA over the disposition of a case. ${ }^{28}$ Therefore, Reutershan filed a $\$ 10$ million personal injury suit in a New York court, naming Dow Chemical and two other manufacturers of Agent Orange as defendants. Shortly before he died, in December 1978, Reutershan founded Agent Orange Victims International (AOVI) and pledged its handful of members to carry on the suit after his 
death. Fledgling organizations already in existence, such as VVAW, Vietnam Veterans of America (VVA), and Citizen Soldier also organized task forces on Agent Orange.

In April 1978, Rep. Ralph Metcalf (D-Ill.), asked the General Accounting Office (GAO) to elicit from the DoD a review of herbicide use in Vietnam. The DoD took the position that only the approximately 1,200 participants of Operation Ranch Hand were at risk. Nonetheless, a computerized record of the spraying missions (called the HERBS tapes) was generated. In December 1978, the VA issued a position paper that noted that the illnesses in the Agent Orange claims were not service-connected since they had not emerged during active duty or within a year after discharge from the service. The VA also required scientific evidence of Agent Orange's harmfulness, based on studies using human subjects, before it would treat or compensate those veterans whose symptoms did meet the criterion of temporal coincidence. These rulings meant that veterans could not receive medical treatment from the VA for Agent Orange-related conditions, nor qualify for compensation. ${ }^{29}$

In January 1979, AOVI immediately hired attorney Victor Yannacone, who refiled Reutershan's complaint as a class-action suit in federal court for all Vietnam veterans and their children who might have been damaged by the herbicide. ${ }^{30}$ The suit named all six manufacturers of Agent Orange-Dow Chemical, Hercules, Northwest Industries, Diamond Shamrock, Monsanto, and North American Phillips - as defendants. Yannacone estimated the damages at $\$ 4$ billion.

Early in 1979, Sen. Charles Percy (R-Ill.) requested a second GAO inquiry into herbicide use in Vietnam. GAO's subsequent report ${ }^{31}$ contended that spraying from aircraft often took place close enough to troops that wind drift may have exposed them to the herbicide ${ }^{32}$ and that ground troops frequently entered contaminated areas shortly after spraying. Further, it stated that troops had used empty herbicide drums for constructing latrines and even homemade hibachis. The report concluded that as many as 40,000 Army, Navy, and Air Force personnel experienced significant exposure to the herbicide. In June 1979, the House Committee on Interstate and Foreign Commerce held the first congressional hearings on Agent Orange and its effects on Vietnam veterans. Veterans with cancer or who had children with birth defects testified before the committee. In response to this hearing, Congress enacted P.L. 96-151 commissioning the VA to conduct an epidemiological study of Vietnam veterans exposed to Agent Orange.

The VA, however, stood firm on its position of requiring scientific 
evidence based on human subjects. By this time, about 750 veterans had submitted claims to the VA and about 5,000 had requested physical examinations or treatment for ailments related to Agent Orange. Angry veterans claimed that requiring definitive scientific proof as a precondition for treatment and compensation ran contrary to the spirit of VA guidelines and placed an extensive burden of proof upon Agent Orange claimants. ${ }^{33}$ These confrontations occurred as VA director Cleland was proudly opening the first Vet Centers, and a frustrated Cleland admitted that many in the VA simply viewed the Agent Orange claims "as a big hoax, like witchcraft." 34

No causal scientific evidence linked Agent Orange with disease and birth defects in human beings. Evidence consisted of personal accounts and claims by veterans, circumstantial evidence from industrial accidents, and scientific studies using animals as subjects. For years, agricultural researchers had conducted research on the active ingredients in Agent Orange, 2,4,5-T and 2,4-D. They knew the ingredients killed plants by mimicking natural plant growth hormones. But the early studies did not ask if the active ingredients could produce abnormal cell growth in animals and humans. During the 1970s, other researchers developed an effective methodology for assessing dioxin - the unintentional by-product in Agent Orange and other herbicides containing 2,4,5-T - and everyone involved soon considered dioxin to be extremely toxic to laboratory animals. However, political divisions within the scientific community - for example, between those who supported and those who opposed the war effort, and between "independent" researchers and those who worked for chemical companies - complicated the debate. ${ }^{35}$

These considerations aside, completion of the requested epidemiological studies would require an enormous amount of time and effort. The time lag between initial exposure and the emergence of serious disease spanned one to two decades and made it difficult to eliminate other potential causes of the disorders. A further complication in the Agent Orange claims was the formidable task of documenting the levels of exposure incurred in Vietnam by ailing veterans. Further, the diseases allegedly caused by dioxin could be produced by factors other than exposure to dioxin since, with the exception of chloracne, exposure to dioxin does not produce one distinctive "signature" disease. Finally, some of the claims of illness lacked credibility because they were not consistent with prevailing medical opinion. Medical researchers simply did not know how dioxin worked, and some of the symptoms attributed to dioxin suggested unfamiliar disease processes. This was especially true of claims by veterans that exposure may have produced birth defects in their children. Medical 
science thought mothers had to be exposed to the toxin during pregnancy. ${ }^{36}$

As the Agent Orange lawsuit dragged into a fourth year, the case was reassigned to Judge Jack Weinstein. Weinstein quickly reconceptualized the case and skewed the options and incentives toward an out-of-court settlement. ${ }^{37}$ On 7 May 1984, nine years to the day after the military evacuated the last American troops from Saigon, Weinstein extracted a cease-fire from lawyers representing the two sides. The manufacturers of Agent Orange agreed to establish a $\$ 180$ million fund from which to compensate veterans who participated in the lawsuit. According to the agreement, establishing the fund did not affirm that exposure to Agent Orange caused or contributed to disease among veterans and did not represent an admission of liability by the chemical companies. Veterans responded to the settlement with varying degrees of disappointment and realism. Particularly galling to the litigants, however, was the lack of answers to questions about dioxin's harmfulness to human beings and about the manufacturer's culpability.

Between 1984 and 1989, four major studies reached various stages of completion: the VA Army and Marine Mortality Study, the Air Force Ranch Hand Study, the Centers for Disease Control Vietnam Experience Study, and the American Legion Health Study. ${ }^{38}$ These research efforts varied by sponsor, purpose, sampling frame, and findings. Congress mandated and paid for the first three studies, and the American Legion, now at the forefront of health care issues for Vietnam veterans, commissioned and paid for the fourth. The findings were inconclusive and on many points contradictory. However, considered in conjunction with other findings, these studies fueled concerns about Agent Orange's harmfulness. Further, the failure of the VA and the Air Force to release their findings promptly, and the failure of the CDC to complete the portion of its study concerning the effects of Agent Orange, reinforced perceptions of bureaucratic foot-dragging and of outright deception and fraud. ${ }^{39}$ Interested persons and groups strongly criticized the purposes and methods of the studies and impugned the motives behind them, while others defended them just as vigorously.

In January 1989, a presidential decree elevated the VA to cabinet status and designated it the Department of Veterans Affairs (DVA). On 1 March, Congress confirmed Edward Derwinsky, a veteran of the Second World War and an Illinois representative to Congress for 24 years, as DVA's first director. During the congressional hearings on his nomination, Derwinsky testified that he had an "open mind" on the Agent Orange controversy. 
On 8 May 1989, a long-awaited ruling on an unpublicized lawsuit broke the lull. Vietnam Veterans of America (VVA) had filed a suit challenging the standards of proof required of veterans claiming injury from Agent Orange. ${ }^{40}$ California Judge Thelton Henderson now ruled that the DVA (previously the VA) had violated congressional intent by insisting on "proof of causal relationship" between Agent Orange and disease, stating that all Congress required was "a significant statistical association" between exposure and medical disorder. The judge also noted that the DVA had compounded the error by failing to give veteran claimants the "benefit of the doubt" as required when claims fell in a grey area.

The question of how to respond to Judge Henderson's ruling became one of Derwinsky's first major policy decisions. The stakes were enormous. If upheld on appeal, Henderson's ruling ultimately would force the DVA to completely rewrite its regulations regarding claims for compensation to those who believed Agent Orange had harmed them. Derwinsky elected to accept the ruling without appeal. Now the question became one of what the policy should be. Derwinsky hired retired admiral Elmo Zumwalt, Jr. as a special consultant on Agent Orange issues, and Derwinsky also directed the DVA's Advisory Committee on the Health-Related Effects of Herbicides to begin an assessment of the literature, disease by disease, for correlational evidence. Those supporting the Agent Orange claimants viewed the selection of Zumwalt as a very positive sign. Zumwalt's son, a Vietnam veteran, had died of non-Hodgkin's lymphoma, and both Zumwalt and his son, in a book written before the latter's death, attributed the cancer to Agent Orange exposure. ${ }^{41}$ Zumwalt also had supported efforts by Agent Orange claimants and, citing Agent Orange and instances from his career in the military, charged that government bureaucracies seldom admit and rectify their mistakes.

The Herbicide committee was made up of researchers from various backgrounds. Some were friendly to Agent Orange claimants, while others were known to lean in the other direction. The committee began with non-Hodgkin's lymphoma. It collected more than 90 studies that considered the relationship between this disease and herbicides containing 2,4,5T or 2,4-D. The committee divided the studies into four categories: valid positive ("sound" study, shows correlation), valid negative (sound study, shows no correlation), valid inconclusive (sound study, findings inconclusive), and invalid (scientifically useless study). The committee classified 4 of the studies as valid positive, 14 as valid negative, and 11 as valid inconclusive. The rest, they concluded, were invalid. The committee met on 31 October 1989 to reach a conclusion. After a morning of discussion, the committee agreed in early afternoon that while it did "not find the 
evidence sufficient" to establish a correlation between Agent Orange and non-Hodgkin's lymphoma, neither could it "rule out such an association." The committee had kicked the decision back to Derwinsky, who now could rule either way.

A month later, Derwinsky announced his decision. He noted that when there is doubt, as the committee said there was, the benefit of the doubt should go to the veteran. DVA, therefore, would extend a presumption of service connection to Vietnam veterans having non-Hodgkin's lymphoma. DVA continues this process to determine which other diseases among Vietnam veterans merit a presumption of service connection.

\section{Discussion}

Similar to veterans of previous wars, Vietnam veterans exhibited pressing and immediate needs in readjusting to civilian life. Many accounts, including some of mine, have emphasized the uniqueness of the problems faced by Vietnam veterans. However, comparisons drawn solely between the Second World War and Vietnam War may overstate the uniqueness of the Vietnam experience. Richard Severo and Lewis Milford make the case that the Second World War, with its broad-based support, victorious culmination, and subsequent largesse in veterans' benefits, was the exception rather than the rule among our nation's wars. ${ }^{42}$ According to them, the pattern of readjustment among Vietnam veterans closely parallels that of veterans of all U.S. wars other than the Second World War. In this century, they argue, the First World War and especially the Korean War provide more appropriate control groups for assessing the Vietnam experience. Korean War veterans, for example, fought in a limited war that ended in a stalemate. A skewed sample of draft-age males participated and, toward the end of the wear, the military used a one-year rotation system. Military psychiatrists grappled with the problem of "combat fatigue" and, following the war, much attention focused on the presumed susceptibility of American prisoners of war to "brainwashing."

In the case of Vietnam veterans, the controversies over PTSD and Agent Orange mark the postwar era. Vietnam veterans were angered by their inability to receive answers to and treatment for troubling and serious health problems. When the VA reacted slowly and reluctantly to their inquiries, they interpreted the VA's hesitancy as a violation of the compensation guidelines and as part of an indifference to them in American society. Therefore, beyond any inherent merits in the claims and counterclaims, the controversies became vehicles for expressing frustrations with 
the war, discontent with the status of Vietnam veterans, generational conflicts, bureaucratic turf battles, and the like. Without demeaning the validity of the veterans' inquiries or the integrity of their opponents, this underscores the importance of symbolic issues.

The story shows that the PTSD and Agent Orange controversies peak and wane on the coattails of a changing array of interested persons and interest groups. The protagonists in each controversy advanced and opposed claims about war trauma and the possibility that an herbicide had harmed American troops. Each side sought dominance amidst uncertainty, conflict, and questions of enormous liability and responsibility. Because PTSD and Agent Orange were controversial matters within the VA and Congress, the veterans' inquiries had no effective representation in the institutions that certify the health problems of veterans as sicknesses. Hence, as we have seen, the veterans introduced their concerns into other arenas. In symbolic struggles of this type, the goal is cultural dominance. The overriding question was, whose version of reality will prevail?

A review of these events has afforded insight into the basic elements of the politics of readjustment. I have identified three themes in this process. By virtue of the free-rider principle, nations accrue an extensive debt to their warriors. This virtually guarantees that veterans' expectations will exceed the public's willingness to provide gratitude and retribution. The use of technological innovations whose repercussions are imperfectly understood makes it very likely that undesirable and unintended compromises to health will occur and provide grounds for claims by veterans. Because the threats are poorly understood, medical authorities may be hard-pressed to deal with the consequences and government officials will be hesitant to take the blame for them. Finally, psychological and physical latent disorders may appear that strain the methods of medical knowledge and health care delivery systems.

The controversies, particularly that of Agent Orange, also point to a significant amount of bureaucratic intransigence. Students of formal organizations sometimes use the concept of the "lazy monopoly" to explain the inertia of large organizations facing demands for change. ${ }^{43}$ The lazy monopoly typically has control over a service or product, and the absence of competition accentuates organizational recalcitrance. Its executives are slow to improve the quality of the product, change their policies, alter the structure of the organization, or assume responsibility for past mistakes. They prefer instead to lose clients or personnel who criticize the organization. In these instances, it typically is necessary to mount initiatives that force change from sources outside the organization itself-hence, the 
significance in these controversies of the courts or of an outside body such as the American Psychiatric Association.

For these reasons, veterans - not just of the Vietnam War, but of any war-often become disgruntled and mount social movements. They are countered by interest groups having something to lose from the challenge. However, the constructivist approach reminds us that this is not peculiar to the world of veterans' issues. Rather, what we see is an especially clear instance of the process by which any issue or condition is defined and recognized as a problem.

\section{Notes}

1. Wilbur J. Scott, "Competing Paradigms in the Assessment of Latent Disorders," Social Problems 35 (1988): 145-61; Wilbur J. Scott, "PTSD in DMS-III: a Case Study in the Politics of Diagnosis and Disease," Social Problems 37 (1990): 294-310; Wilbur J. Scott, "The Politics of Psychological Counseling for Vietnam Veterans," Spring 1991; and Wilbur J. Scott, "Vietnam Veterans against the War: the Politics of Antiwar Protest," in Perspectives on Social Problems, ed. John Holstein and Gale Miller, vol. 4 (Greenwich, Conn.: JAI, 1992).

2. See Malcolm Spector and John Kitsuse, Constructing Social Problems (Menlo Park, Calif.: Cummings, 1977 and Hawthorne, N.Y.: Aldine, 1988); and Armand L. Mauss, Social Problems as Social Movements (Philadelphia: J.P. Lippincott, 1975) and Armand L. Mauss, "Beyond the Illusion of Social Problems Theory," in Perspectives on Social Problems, ed. G. Miller and J.A. Holstein, vol. 1 (Greenwich, Conn.: JAI, 1989), 1939.

3. William F. Ogburn originally developed the thesis, known as "cultural lag theory," that technological innovations are adopted and implemented more rapidly than are the norms for dealing with their consequences. See William F. Ogburn, Social Change: With Respect to Culture and Original Nature (New York: Viking, 1939), $200-01$.

4. The VA automatically considers a health problem service-connected if its examiners agree that the etiology of the problem occurred during military service and if the veteran can document that symptoms occurred during military service or within a year after discharge from the service.

5. See James Buchanan, "The Potential for Taxpayer Revolt in American Democracy," Social Science Quarterly 59 (1979): 692. The free-rider principle states: "If the benefits of an action are ... well-defined while the costs ... are generalized, ... individuals will act without regard to the costs involved. ... Conversely, if the costs are ... welldefined while benefits are ... generalized, ... individuals will ... refrain from taking certain actions."

6. More than 3 million of the 12 million veterans of the Second World War joined the American Legion, VFW, or Disabled American Veterans, and, by 1948, 92 veterans of that war-almost 20 percent of the combined House and Senate-were in Con- 
gress. In contrast, less than 100,000 of the roughly 9 million Vietnam-era veterans joined these organizations during the 1970 s. As late as 1978 , only 11 Vietnam-era veterans were serving in Congress.

7. See Peter G. Bourne, Men, Stress, and Vietnam (Boston: Little, Brown, 1970).

8. Particularly influential were the works of Roy R. Grinker and John P. Spiegel, Men under Stress (Philadelphia: Blakiston, 1945) and Abram Kardiner, War, Stress and Neurotic Illness (New York: Paul B. Hoeber, 1947).

9. Herbert C. Archibald, D.M. Long, and Read D. Tuddenham, "Gross Stress Reaction in Combat - a 15-Year Follow-up," American Journal of Psychiatry 119 (1962): 31722; Herbert C. Archibald and Read D. Tuddenham, "Persistent Stress Reaction Following Combat: a 20-Year Follow-up," Archives of General Psychiatry 12 (1965): 474 81.

10. See, for instance, Jim Goodwin, "The Etiology of Combat-Related Stress Disorders," in Post-Traumatic Stress Disorders, ed. Tom Williams (Cincinnati, Ohio: Disabled American Veterans National Headquarters, 1987). Goodwin argues that the most important factor producing the differences was the 12-month rotation system - troops knew exactly how long they had to endure and struggled successfully to prevail until their time came to go home.

11. Arthur S. Blank, Jr., "Irrational Responses to Post-Traumatic Stress Disorder and Viet Nam Veterans," in The Trauma of War: Stress and Recovery in Viet Nam Veterans, ed. Steven M. Sonnenberg, Arthur S. Blank, Jr., and John A. Talbott (Washington, D.C.: American Psychiatric Association, 1985), 73-74.

12. John Talbott, who served in Vietnam as a psychiatrist, recalls: "(In 1970 or 1971) I was asked to evaluate a disability case for the VA by Ed Koch, who then was a representative to Congress.... I looked at this kid ... (and) ... videotaped him. He was such a classic case ... (of) mental instability related to combat experience that I presented it to my class at Columbia (University Medical School) on stress disorders. (Psychiatrist) Larry Kolb was the senior person in that class and (he) came up to me afterward and said, 'How on earth did you find this person?' He had sleep disturbances, he had startle reaction, he had everything. Had everything. And I had it all on videotape.... I said, 'This is a guy who has been disallowed benefits by the VA because he doesn't have a combat-related disorder!' " John Talbott, telephone interview with author, 24 February 1989, Baltimore, Md.

13. Sarah Haley, a longtime psychiatric social worker with the Boston VA, states: "The three or four people who were listing traumatic war neurosis ..., they would see it as their job ... to talk with the person about what had happened in Vietnam... 'Oh, you lost this buddy, you lost that buddy, and that happened. Well, what do you think about it now? Oh, I see, you blame yourself. You think if you had only (acted differently), this wouldn't have happened. I see. No wonder you feel so terrible....' I drew up a schedule of our intake meetings. There was a different team for each halfday. I highlighted in red the people who it was worthwhile for the vets to see, those people who would be empathetic. I marked the others in black, skull-and-crossbones don't send anyone to this team!" Sarah Haley, personal and telephone interviews with author, 25 October 1988, Dallas, Tex. and 9 November 1988, Somerville, Mass. 
14. Chaim F. Shatan, "The Post-Vietnam Syndrome," New York Times, 26 May 1971, A35; Chaim F. Shatan, "The Grief of Soldiers in Mourning: Vietnam Combat Veterans' Self-Help Movement," American Journal of Orthopsychiatry 45 (1973): 640-53.

15. Guy McMichael, who served as legal counsel for the Senate Committee on Veterans' Affairs from 1971 to 1976 recalls: "The House Committee was dominated ... by World War Two veterans with very distinguished careers both in the military and in Congress. ... And I think there was a generational thing here.... (Olin) Teague certainly had the attitude, well, you know, this is tough but we sucked it up, and we didn't need to go into... counseling and I am not sure that Vietnam veterans need this kind of counseling." Guy McMichael, interview with author, 9 March 1989, Washington, D.C.

16. Max Cleland, consultant to the Senate Committee on Veterans' Affairs in 1975 and later national director of the VA under President Jimmy Carter, states: "(The American Legion and VFW) gave great lip service to Vietnam veterans, mostly because they wanted them to join the organizations and boost their ranks. But when it came time to fund programs for (Vietnam veterans), boy, they thought it was going to take away from them. And they, I found, ... fought tooth-and-nail, mostly behind the scenes, to gut a lot of this (legislation for Vietnam veterans)." Max Cleland, telephone interview with author, 27 January 1989, Atlanta, Ga.

17. David Bonior (D-Mich.), a Vietnam-era veteran elected to Congress in 1976, later wrote of the stalemate: "Tiger Teague was prepared to fight against the major (veterans) organizations.... The veterans organizations constantly sought more.... The role of responsible leadership was to root out the legitimate requisitions from the boondoggles. ... The veterans organizations would not fail to advance needed programs. No chairman needed to argue for programs against hesitant veterans groups. Abandoned by the major veterans organizations, Vietnam veterans needed an ally among the barons, one who would stand with them against the major veterans groups. The role was unintelligible to Chairman Teague.” David Bonior, Stephen Champlin, and Tim Kolly, The Vietnam Veteran: A History of Neglect (New York: Praeger, 1984), 137.

18. Word had reached Shatan informally that "no change (was) planned" in DSM-III for a stress reaction associated with combat. In 1975, psychiatrist Robert Spitzer, editor of DSM-III, appointed Lifton, Shatan, and Smith to the APA's Committee on Reactive Disorders along with himself and psychiatrists Nancy Andreason and Lyman Wynne. This provided the working group a formal entry into the preparation of DSM-III. Chaim Shatan, interview with author, 24 October 1988, Dallas, Tex.

19. See, for instance, John E. Helzer, Lee N. Robins, and D.H. Davis, "Antecedents of Narcotic Use and Addiction: A Study of 898 Vietnam Veterans," Drug and Alcohol Dependence 1 (1976): 183-90; and John E. Helzer, Lee N. Robins, and D.H. Davis, "Depressive Disorders among Vietnam Returnees," Journal of Mental and Nervous Disorders 168 (1976): 177-85.

20. Diagnostic and Statistical Manual of Mental Disorders, 3d ed. (Washington, D.C.: American Psychiatric Association, 1980), 236.

21. On 13 July 1979, President Jimmy Carter signed Public Law 96-22, which funded the Outreach Program and declared a week honoring Vietnam veterans. David Broder of 
the Washington Post observed: "As their price for approving the special treatment for the ... Vietnam vet, members of the House Veterans' Affairs Committee have demanded from the president and the Veterans Administration veto power over all significant future VA hospital and medical facility construction. ... Next to tipping over a wheelchair, it is hard to imagine a shabbier way for Congress to mark Vietnam Veterans Week." Quoted in Bonior et al., Vietnam Veteran, 134.

22. Cleland explains the need for the Vet Centers as follows: "(The VA) was bogged down in bureaucracy, especially to the non-service-connected veteran backed up by veterans organizations that have non-service-connected members by the millions.... And so, the tail begins to wag the dog, and your priorities get out of joint. So Vietnam veterans didn't fit the profile, they didn't fit the veterans organizations, they didn't fit the attitude of the country, didn't fit the existing bureaucracy. And the class of '46, as World War Two vets are affectionately known, thought (we) were a bunch of cry-babies, weirdos, and barn burners. ... And when I got there in '77, the class of ' 46 was running the agency and every major department. You understand what I'm saying? ... (Y)ou had to bypass the whole bureaucracy to set the thing up." Cleland interview.

23. Vet Centers referred veterans needing more intensive therapies to VA hospitals.

24. For a report containing a chronology of events involving herbicides containing 2,4,5T, see "The Health Effects of Herbicide 2,4,5-T" (New York: American Council on Science and Health, 1981), 3-4.

25. The U.S. Air Force assigned the spraying mission to the 309th Air Commando Squadron and designated the program "Operation Hades." It later was given the more neutral designation, "Operation Ranch Hand." The squadron, whose members coined the motto, "Only We Can Prevent Forests," sprayed large tracts of terrain from C-123 transport planes equipped with storage tanks and high-pressure nozzles. Other military units sprayed much smaller areas using helicopters, trucks, and backpacks to transport the herbicide.

26. Bill Kurtis, Bill Kurtis on Assignment (Chicago: Rand-McNally, 1983).

27. Rep. Abner Mikva (D-Ill.) of Chicago arranged for a subsequent screening of the documentary before the House Committee on Veterans' Affairs. He invited other interested parties, including administrators from the VA, the Environmental Protection Agency (EPA), and the chemical companies who manufactured Agent Orange.

28. See Feres v. The United States of America, 340 U.S. 135, 1950; Pamela Lacy and Vincent Lacy, “Agent Orange and Government Responsibility for the Military Use of Herbicides." Journal of Legal Medicine 3 (1982): 137-78, esp. 153-58; and Peter Schuck, Agent Orange on Trial: Mass Toxic Torts Disasters in the Courts (Cambridge: Harvard University Press, 1986), esp. 58-69. See also Dean Phillips, "Subjecting the Veterans Administration to Court Review," in Strangers at Home: Vietnam Veterans since the War, ed. Charles Figley and Seymour Leventman (New York: Praeger, 1980), $325-41$.

29. At the same time, the Environmental Protection Agency announced that it would revoke the registration of products containing 2,4,5-T unless manufacturers could document its safety for humans. The agency encouraged interested parties, including 
the general public, to submit information concerning exposure to the herbicide and health problems.

30. See Reutershan et al. v. The Dow Chemical Co. et al. and The United States of America, no. 78-CV-4253, (S.D.N.Y.), filed 9 January 1979. Further legal developments are filed under: In re "Agent Orange" Product Liability Litigation (MDL no. 381), 475 F. Supp. 928, E.D.N.Y., 1979; 635 F. 2d 987, 2d Cir., 1980; 454 U.S. 1128, 1981; 597 F. Supp. 740, E.D.N.Y., 1984, Weinstein, C.J.

31. "U.S. Ground Troops in South Vietnam Were in Areas Sprayed with Herbicide Orange,” FPCD-80-23 (Washington, D.C.: U.S. General Accounting Office, 1979).

32. Air Force officer Alvin Young, who tested the spraying equipment at Eglin Air Force Base, disagrees that wind drift was a factor: "In the spraying of malathion, ... every few inches you had $t$-jet nozzles on the spray boom ... and this ... generated ... a 30 micron particle size... (that) you needed to be effective against the vectivecarrying insects.... (In) the case of the herbicide... you were looking for large particles, because you wanted them to come straight down. And so, we removed most of the nozzles but we flared the pipes coming out of the boom.... (T)hat gave us a particle size of about $250-260$ microns. ... Which meant that spray drift was still possible but only marginal. We're talking yards, you're not talking quarters or a half a mile. I stood underneath many, many spray flights." Alvin Young, interview with author, 6 March 1989, Washington, D.C.

33. The Bradley Commission recommended two guidelines for compensating veterans. First, the highest priority should go to programs that extend medical care for serviceconnected injuries or illnesses, ease reentry into civilian life, and provide adjustments for career advantages lost while in the service. Second, when there is a doubt about a claim, the veteran should be given the benefit of the doubt. See "Veterans Benefits in the United States: A Report to the President by the President's Commission on Veterans' Pension" (Washington, D.C.: House Commission Print no. 235, 84th Cong., 2d sess., 1956).

34. Quoted in Bonior et al., Vietnam Veteran, 167. Further, Cleland states: "Part of the frustration for me was to go to a city ... to open up a Vet Center, you know, something that you know is absolutely demonstrable, and you've been working for four years to sell it to Congress, sell it to the media,... to the White House, ... to the agency, ... to the veterans' organizations, and finally you've got a tangible ... product here that you're able to deliver for Vietnam veterans. And you get Mau-Maued by a bunch of guys dressed in orange shirts ... ! I mean, I was out with (Sen.) Cranston in Los Angeles, and ... some psyched-out Vietnam vet took a swing at me! ... I mean, the Agent Orange believers, there was no rationale, there was no discussion, it was all screaming, it was all emotion, it was all 'you are wrong and we all are right!'” Cleland interview.

35. For example, Alvin Young, who holds a Ph.D. in herbicide physiology, says of a research team that visited Vietnam in 1971 and of subsequent research: "Their agenda was not an agenda that talked about the health of the Vietnamese people. Their agenda was ... they were wanting the military of the United States out of Vietnam. . . I think the fair assumption would be (that) most of the people who have ever had any experience with the herbicide - the agricultural community, the section of the public community who had experience with herbicides-probably lined up more with the 
military and the (position) that it was unlikely that there were health problems. But, it's clear that Department of Agriculture never defended Department of Defense." Young interview.

36. Subsequent research has explored the possibility that toxins to which males are exposed prior to reproductive activity are linked to birth defects. For example, Hales and her associates now have reported that a toxin introduced into male mice accrued in the reproductive tract and subsequently was transmitted to female mice during mating, thereby "altering progeny outcome." See Barbara Hales, Susan Smith, and Bernard Robaire, "Cyclophosphamide in the Seminal Fluid of Treated Males," Toxicology and Applied Pharmacology 84 (1986): 423-30.

37. Peter Schuck writes: "To try such a case, (Weinstein) felt, would consume an almost unthinkable amount of time ..., money, talent, and social energy, and with the inevitable appeals and possible retrials, the outcome might be uncertain for many years to come. ... Finally, a negotiated settlement offered the prospect of everybody obtaining something rather than one losing everything." See Schuck, Agent Orange, 143.

38. See George Lathrop et al., Ranch Hand II. An Epidemiological Investigation of Health Effects in Air Force Personnel Following Exposure to Herbicides (San Antonio, Tex.: Brooks Air Force Base, 1984); Patricia Breslin et al., "Proportionate Mortality Studies of U.S. Army and U.S. Marine Corps Veterans of the Vietnam War," Journal of Occupational Medicine 30 (1988): 412-419; the American Legion study appeared as a series of articles in Environmental Research 47 (1988): 109-209; and Health Status of Vietnam Veterans, vol. 1, Synopsis (Atlanta: Centers for Disease Control, 1989).

39. The VA study, which showed higher mortality rates for exposed Marines, was withheld for six months while it underwent a review process for publication. The Air Force released a summary report of the Ranch Hand study, but not the detailed reports that showed health "abnormalities" among the Ranch Handers. Finally, retired Army colonel, Richard Christian, who was hired to assemble relevant military records and whose team developed the "hits method" for documenting exposure, asserts that CDC's decision to discontinue the Agent Orange study was based on political, not scientific, grounds. Richard Christian, interview with author, 14 March 1991, Washington, D.C.

40. See Vietnam Veterans of America (VVA) Staff Report, "Victory: VVA Wins A/O Judgment," Veteran 9 (June 1989): 6, 11, 22, and 28.

41. See Elmo Zumwalt, Jr. and Elmo Zumwalt 3d, "Agent Orange and the Anguish of an American Family," New York Times Magazine, 24 August 1986, 32-40, 49, and 58. Ironically, the decision to use Agent Orange in the area of operation in which Zumwalt $3 \mathrm{~d}$ served was made by his father. Admiral Zumwalt states that he would make the same decision even now since, in his view, the use of the herbicide reduced combat fatalities. Elmo Zumwalt, Jr., telephone interview with author, 4 April 1989, Arlington, Va.

42. Richard Severo and Lewis Milford, The Wages of War: When American Soldiers Came Home - from Valley Forge to Vietnam (New York: Simon and Schuster, 1989).

43. See Albert Hirschman, Exit, Voice, and Loyalty: Responses to Decline in Firms, Organizations, and States (Cambridge: Harvard University Press, 1970), and John Seidler, "Priest Resignations in a Lazy Monopoly," American Sociological Review 44 (1979): 763-83. 